\title{
Marek Osiewicz
}

Instytut Filologii Polskiej Uniwersytetu im. Adama Mickiewicza w Poznaniu

\section{Oznaczanie palatalności $l \mathbf{w}$ drukach polskich z XVI wieku' ${ }^{1}$}

Niniejszy artykuł stanowi prezentację wyników analizy sposobu i zakresu graficznego sygnalizowania palatalności staropolskiego $l$ ' w polskich tekstach drukowanych z XVI wieku. Uwzględnione zostały różnorodne uwarunkowania tego zjawiska: funkcjonalne (fonologiczne), frekwencyjne, kontekstowe (graficzne i fonetyczne), tekstowe (w tym też gatunkowe oraz idiolektalne), regionalne oraz wydawnicze; uzyskane dane były konfrontowane z wynikami analizy oznaczania palatalności $l \mathrm{w}$ listach polskich z lat 1525-1548 [Osiewicz 2002].

Podstawę źródłową analizy stanowi grupa 177 tekstów drukowanych wchodzących w skład korpusu online SXVI (o łącznej długości ok. $35 \mathrm{mln}$ liter). W czasie, w którym ekscerpowano te teksty, korpus elektroniczny różnił się od korpusu wydania papierowego słownika nieobecnością jedynie 3 tekstów $\left(\text { SienLek, } \mathrm{March}^{2} \text { i } \mathrm{March}^{3}\right)^{2}$ oraz częściowym tylko uwzględnieniem tekstu słownika Jana Mączyńskiego (k. 1-344, co stanowi ok. 3/5 całego tekstu Mącz). Poświadczone w źródłach SXVI zapisy etymologicznego l' z oznaczoną palatalnością wyłoniono, wykorzystując elektroniczne narzędzia przeszukiwania tekstów (wyszukiwarki ciągów znaków zaimplementowane w przeglądarce internetowej Opera oraz w programie Adobe Acrobat Reader). Formy opozycyjne (a więc bez oznaczonej palatalności), ze względu na wynikającą z objętości korpusu dużą liczbę poświadczeń oraz ich kontekstową nieodróżnialność od zapisów $l \mathrm{w}$ formach łacińskich licznie pojawiających się w badanych

1 Artykuł publikowany in memoriam Profesora Wojciecha Ryszarda Rzepki przez Uczestnika seminarium Polszczyzna doby staro- $i$ średniopolskiej, Poznań, 21-23 stycznia 2019 roku.

2 Rozwiązanie skrótów odnoszących się do tekstów źródłowych SXVI zob. SXVI I: XLIV-CI. 
tekstach, charakteryzowane będą za pomocą bezwzględnych danych wyłącznie w odniesieniu do zapisów zlokalizowanych w tekstach poświadczających formy z oznaczoną palatalnością $l$; w zestawieniu ogólnym użyte zostaną wielkości szacunkowe (metoda ich pozyskania zostanie przedstawiona w odpowiednim przypisie). $\mathrm{Z}$ analizy wykluczono poświadczenia spółgłoski $l$ zlokalizowane w wyrazach obcych oraz w obcych nazwach własnych.

Istotną część przedstawianych wyników badania stanowi ich konfrontacja z wynikami analizy przeprowadzonej na materiale listów polskich z drugiej ćwierci XVI wieku. Bazy źródłowe zestawianych analiz wykazują zarówno podobieństwa, jak i różnice [charakterystyka obu grup tekstów źródłowych zob. Osiewicz, Piotrowska 2007; Osiewicz 2007: 9-12]. Łączą je: zbliżona liczba tekstów (druki 177 || listy 185), zbliżona liczba ich autorów (nadawców) (druki 95 || listy 88), reprezentacja regionalna obejmująca najważniejsze regiony dialektalne (Małopolska, Wielkopolska, Mazowsze, Kresy płn. ${ }^{3}$ ) - proporcje źródeł pochodzących z poszczególnych regionów (ustalane na podstawie pochodzenia autorów) nieco jednak różnią się: wśród druków najwięcej jest tekstów autorstwa Małopolan i Wielkopolan (95 i 61 tekstów \| Mazowsze 30 tekstów || Kresy płn. 3 teksty), w grupie listów o weryfikowalnej przynależności regionalnej przeważają teksty pochodzące z Kresów płn. (55 listów || Wielkopolska 20 listów || Małopolska 14 listów || Mazowsze 13 listów). Odmienna jest natomiast reprezentacja chronologiczna obu baz. Druki z bazy źródłowej SXVI reprezentują okres zawierający się w latach 1513-1600 (choć jest to reprezentacja nierównomierna, rosnąca wraz z upływem czasu ${ }^{4}$ ), w bazie listów polskich znalazły się natomiast teksty powstałe wyłącznie w drugiej ćwierci XVI wieku. Najistotniejsza różnica zachodząca między obiema grupami tekstów dotyczy ich objętości - pod tym względem bazy te stanowią zbiory niemal nieporównywalne: łączna długość tekstów drukowanych liczona w literach wynosi ok. $35 \mathrm{mln}$, listy natomiast stanowią bazę materiałową o objętości ok. 165 tys. znaków. O tej dysproporcji pamiętać należy zwłaszcza przy interpretacji wyników analiz wykorzystujących dane o charakterze morfemowym - przekrój morfemowy baz źródłowych jest wszak ściśle uzależniony od objętości tworzących je tekstów [zob. SXVI I: XIV-XV]. Geneza rękopiśmiennej tradycji oznaczania palatalności $l$ związana jest z potrzebą odróżniania dwóch fonemów: przedniojęzykowo-zębowego $t$ i śred-

3 Choć w listach brak tekstów o pewnej proweniencji śląskiej i południowokresowej, obecnych w bazie źródłowej SXVI.

4 Dla poszczególnych dwudziestopięcioleci XVI wieku reprezentacja tekstów drukowanych w bazie elektronicznej SXVI przedstawia się następująco: 1500-1524 - 6 tekstów; 1525-1549 - 22 teksty, 1550-1574 - 59 tekstów, 1575-1600 - 88 tekstów. 
niojęzykowo-dziąsłowego l' [Dejna 1993: 114-115]. W tradycji tej sygnalizowanie palatalności l'za pomocą zapisów „ly” lub „li” było początkowo jedyną formą graficznego odróżniania obu fonemów - np. w listach polskich z lat 1525-1550 alternatywny sposób ich odróżniania poświadczony został tylko w urzędowej kopii listu Stanisława Dowojny do Mikołaja Radziwiłła Rudego (choć niekonsekwentnie: $l=, 11$ ” $\|, l^{\prime \prime}, l^{\prime}=$, ,ly") 5 [Listy I: $\left.168^{6}\right] \mathrm{i}$ - już regularnie - w listach Stanisława Koszutskiego (,," 1 ,l”) [Listy II: 303, 315, 316, 320, 323, 328, 347, 349, 358, 365, 367; por. też Stęplewski, Osiewicz 2004: 367]. W drukach polskich z XVI wieku funkcję graficznego odróżniania $t$ od $l$ ' pełni stosowanie osobnego znaku (,l” kreślone lub z pętelką) na oznaczenie fonemu $t$ - tym samym uznać należy, że w tekstach tych obecność oznaczeń palatalności l' ma charakter niezamierzonego przejęcia z odmiennej w tym zakresie, zwyczajowej wówczas pisowni rękopiśmiennej. Oznacza to, że pisownia druków nie może bezpośrednio świadczyć o zmianach zachodzących w fonetycznej realizacji fonemu $l$ ' - zastosowana w drukach metoda odróżniania bliskich sobie fonemów płynnych niedrżących była z zasady nieczuła na przebiegający w XVI wieku proces depalatalizacji l' [o chronologizacji i fonetycznych uwarunkowaniach tego procesu zob. Stieber 1962: 70-71; Stieber 1974: 286-289; Dejna 1993: 114-15]7. Wśród ekscerpowanych druków XVI-wiecznych regule „nowego" rozróżniania omawianych fonemów wymykają się jedynie 3 teksty: zachowany fragment Raju dusznego Biernata z Lublina (Ungler, Kraków 1513), w którym z pełną konsekwencją zastosowano rękopiśmienny zwyczaj ich oznaczania (por. np. l': kofczyelye 17v, dlya 18, lyubofcy 19, wilyal 'wylał' 21v, alye $23 \mathrm{v}$, lyuba $23 \mathrm{v}$; $t$ : obyecal 16, mogl 18v, lafkawye 19, ochlodzenya 21 , ftluczonim 21v), Powieść o papieżu Urbanie (Haller, Kraków 1514), w której na oznaczenie obu fonemów użyty został jeden znak „l” (z 5 odstępstwami od tej zasady w postaci zapisów l' = „ly": czyelye zzny 1, przyyaczyelye 1, lyath 2, mylye 3, wefzelye 3v), oraz Żywot Pana Jezu Krysta Baltazara Opeca (Ungler, Kraków 1522), również z jednym znakiem „l” na oba fonemy i tylko jednym zapisem l' za pomocą „ly” (alie 92) [por. też Kamińska 1953: 20]. Z tego powodu materiał graficzny wyekscerpowany z tych 3 druków (liczący 85

5 Choć w listach Dowojny będących autografami stosowane jest oznaczanie tradycyjne: „1” i ,ly” [Listy I: 178, 181].

6 Przy odsyłaczach do listów cyfra po dwukropku oznacza numerację korespondencji przyjętą w cytowanym zbiorze.

7 Pisownia rękopisów ma w tym względzie przewagę, ponieważ - jak wiadomo - radziła sobie ona również bez oznaczania opozycji między $l$ i $l$ ' - oba fonemy często oznaczane były za pomocą jednej litery „,” [Kamińska 1953: 20-21; Lisowski 2001: 52]. 
zapisów z oznaczoną palatalnością $l$ ) został wyłączony z analizy - jest świadectwem odmiennej praktyki pisownianej.

W drukach stanowiących bazę źródłową SXVI palatalność $l$ oznaczana jest za pomocą trzech liter (dołączanych do litery „,l” w pozycji przed samogłoską): „i”, „y” oraz ,j”. Najczęściej w funkcji tej poświadczona została litera „i” (2104 razy, 92\%, np. napodlieyfzy CzahTr B, rolia Goski Av, daliéy HistJóz D4, wefelie KlerWes A2v, pliony KlonWor 1, wfzeliákim KuczbKat 315, bliufzcżu Leop QQqq2v, fliofárfkie Mącz 193v, zlie Mącz 263, paliecz Mymer $^{1}$ 21, liekárftwo Oczko 41, zafliépienje RejKup r7, Kliucże RejKup t7v, śliad 580 SkarŻyw 580), znacznie rzadziej do oznaczenia palatalności $l$ użyto litery „y” (182 razy, 8\%, np. śmyelye HistJóz D3, lyáthá Murm 7, Malyowánye Murm 127, przeklaczye PatKaz III 115v, myflyę RejKup e3v, wfzelyáki RejPs $219 \mathrm{v}$ ), odnotowano też jeden zapis palatalnego $l \mathrm{z}$ wykorzystaniem litery ,j” (0,04\%: vljana 'ulana' RejKup t8). Proporcje te odwzorowują ogólną tendencję do oznaczania palatalności spółgłosek w pozycji przed samogłoską za pomocą litery „,", zaznaczającą się w drukach polskich już od początku XVI wieku [Lisowski 2001: 82-93]. Użycie w tej funkcji litery „y” jest reliktem epoki rękopiśmiennej, co wynika zarówno z lokalizacji tychże zapisów w drukach - głównie w tekstach wczesnych (Murm „y” 94 razy \|| „’” 4 razy [zob. też Cygal-Krupowa 1979: 78-79], HistJóz 1 raz || 3 razy) oraz w niedbale złożonym słowniku Calepina (,y” 32 razy $\|$,,i” 1010 razy) [Oestrreicher 1927: 468-469, zob. szerzej przyp. 9], a także w utworach Mikołaja Reja (RejKup „y” 21 razy $\|$, ," 334 razy, RejPs 34 razy $\| 13$ razy) [zob. też Kuraszkiewicz 1986a: 614] - jak i ze stanu poświadczanego przez listy polskie, w których oba sposoby oznaczania palatalności $l$ charakteryzują się niemal identyczną liczbą użyć („li” 683 razy \| „ly” 676 razy). Być może rękopiśmienną proweniencję ma również jedyna w drukach forma z „lj”, poświadczona w RejKup - formy tego typu dość licznie pojawiają się w listach (318 razy), w których charakterystyczne są przede wszystkim dla korespondencji pochodzących z Kresów płn. Radziwiłłów (Mikołaja Czarnego, Mikołaja Rudego i Barbary Radziwiłłówny). Niewykluczone jednak, że w tym przypadku mamy do czynienia z poświadczanym również $w$ innych tekstach drukowanych zjawiskiem wykorzystywania litery , j” jako wariantu liter „y" oraz „i” (por. nawet w tym samym wersie: Ze Srzjbra vljana czjfta RejKup t8; inne przykłady: wychwjczę t7v, przjpjfuye Tv, mienj aa3v, rzeczj aa7) ${ }^{8}$.

8 O zjawisku zastępowania litery „y” węższym odpowiednikiem ,j” w drukach XVI-wiecznych zob. Osiewicz 2013: 168, 2016: 326, 2017: 119-120. 
W ekscerpowanej bazie tekstowej palatalność $l$ oznaczono 2287 razy, co stanowi - w przybliżeniu 9 - $0,1 \%$ wszystkich zapisów kontynuantów etymologicznego *l' (ok. 231500 razy); w grupie tekstów poświadczających omawiane zjawisko pułap oznaczeń palatalności wynosi 2\% (l' 2287 razy $\| l 109825$ razy). Odsetkowy zasięg występowania analizowanego zjawiska jest w drukach wyraźnie marginalny i mocno kontrastuje z danymi charakteryzującymi listy, w których 1677 oznaczeń palatalności $l$ stanowi aż 65\% wszystkich zapisów tej głoski (w grupie listów oznaczających palatalność - 70\%). Wymowę tych obserwacji dopełniają dane dotyczące tekstowego przekroju omawianego zjawiska. W grupie druków formy z oznaczoną miękkością $l$ poświadczone zostały w 42 tekstach, czyli w $24 \%$ wszystkich tekstów tworzących tę bazę. W listach przekrój tekstowy poświadczeń zapisów z $l$ palatalnym jest znacznie bogatszy - formy tego typu zapisane zostały w 162 tekstach, czyli w $88 \%$ całego zbioru [Osiewicz 2002: 67].

Ważnych obserwacji dostarcza analiza chronologicznego zróżnicowania obecności palatalnego $l \mathrm{w}$ drukach XVI-wiecznych. Z danych zawartych w tabeli 1 wynika, że liczba wystąpień zapisów z oznaczoną palatalnością $l$ wykazuje tendencję malejącą - świadczy o tym zarówno zmiana wartości odsetka poświadczeń (okres I 4,6\%, okres II 3,6\%, okres III 1,1\%, okres IV $0,1 \%{ }^{10}$ ), jak i malejąca od okresu II wartość procentowa tekstów notujących takie zapisy (okres I 33\%, okres II 55\%, okres III 25\%, okres IV 16\%). Zwraca jednak uwagę to, że znaczniejszy spadek poświadczeń $l$ ' rozpoczyna się dopiero od okresu III - w pierwszej połowie XVI wieku w tekstach drukowanych zjawisko oznaczania palatalności $l$ ma zbliżoną charakterystykę statystyczną (choć pamiętać należy, że w okresie I poświadczenia tego typu notowane są tylko w 1 tekście: March ${ }^{1}$ ).

Zjawisko oznaczania palatalności $l$ wykazuje zależność od kontekstu fonetycznego. W drukach analizowane zapisy poświadczone zostały wyłącznie w pozycji przedsamogłoskowej; w tym zakresie grafia ta nie odbiega od zwy-

9 W grupie tekstów nienotujących oznaczeń palatalności $l$ liczbę poświadczeń zapisów z kontynuantem psł. *l' wyznaczono szacunkowo, wykorzystując obliczony na podstawie pozostałych tekstów średni stosunek ogólnej liczby liter poszczególnych tekstów (podanych w SXVI I: XLIV-CI) do liczby wszystkich wystąpień $l(\mid l$ ') (wynoszący 142) i wskazaną w SXVI „literową" objętość tekstów.

10 Z zestawienia dla OIV usunięto Calep - wysoki odsetek poświadczanych w tym źródle postaci z oznaczoną palatalnością $l(39,4 \%)$, wyraźnie zawyżający wskazania odsetkowe charakteryzujące teksty z tego okresu (2,9\% zamiast $0,2 \%)$, jest skutkiem niedbałego składu, w którym udział brali zecerzy nieznający języka polskiego, zapewne z tego powodu polegający na grafii podstawy rękopiśmiennej polskiej części tego słownika [por. np. Oestrreicher 1927: 468-469]. Zob. też pkt 10 artykułu. 
Tabela 1. Zróżnicowanie chronologiczne oznaczeń palatalności $l$ w tekstach drukowanych

Oznaczenia palatalności $l$

\begin{tabular}{lrrrc}
\multicolumn{1}{c}{ Okres } & liczba & odsetek & $\begin{array}{c}\text { liczba } \\
\text { tekstów }\end{array}$ & $\begin{array}{c}\text { odsetek } \\
\text { tekstów }\end{array}$ \\
\hline I: $1500-1524$ & 9 & 4,6 & 1 & 33 \\
\hline II: $1525-1549$ & 588 & 3,6 & 12 & 55 \\
\hline III: $1550-1574$ & 639 & 1,1 & 15 & 25 \\
\hline IV: $1575-1599$ & 1051 & $2,9(0,1)$ & 14 & 16
\end{tabular}

Źródło: opracowanie własne.

czajowej pisowni rękopiśmiennej - w listach zasięg zjawiska jest identyczny. W bazie źródeł SXVI najwyższy odsetek oznaczeń palatalności $l$ (zob. tabela 2.) zaznaczył się w pozycji przed samogłoską nosową ę (4,4\%), stosunkowo wysokimi wskazaniami zjawisko to cechuje się też w pozycji przed samogłoskami $a(2,8 \%)$ oraz $e(2,5 \%)$; znacznie niższą wartością odsetkową charakteryzują się oznaczenia palatalności $l$ przed samogłoskami nieprzednimi ustnymi $o$ oraz $a(1,5 \%)$, najniższą zaś wartość współczynnik ten przyjmuje dla pozycji przed samogłoską $u$ (tylko $0,7 \%$ ). Proporcje przedstawionych wskaźników nie pokrywają się ze stanem poświadczonym w listach, choć różnice obejmują tylko dwie pozycje: $+u$, w której w obu grupach tekstów oznaczenia palatalności $l$ przyjmują skrajnie odmienne wartości (w listach jest to pozycja o najwyższym poziomie oznaczeń $-87,3 \%$, w drukach w pozycji przed samogłoską $u$ palatalność $l$ oznaczona została natomiast najmniej konsekwentnie - 0,7\% wystąpień), i $+o$, w której w drukach oznaczenia palatalności $l$ osiągają taki sam pułap poświadczeń, jak w pozycji $+a(1,5 \%)$ - odmiennie niż w listach, gdzie obie pozycje dzieli ponaddziesięcioprocentowa różnica $(+a 62,6 \%$, +o 47,8\%). W pozostałych pozycjach notowania są zbieżne - w obu grupach tekstów stosunkowo wysoki odsetek oznaczenia palatalności $l$ poświadczony został w pozycji przed samogłoskami nosowymi i przed samogłoską $e$. Fakt ten stosunkowo łatwo wyjaśnić w odniesieniu do pozycji przed samogłoskami ę i $e$, które z uwagi na swą przednią artykulację miały naturalną zdolność do podtrzymywania palatalności poprzedzających spółgłosek. Nie udało się dotąd przekonująco wyjaśnić wysokiego poziomu oznaczeń palatalności $l$ przed nieprzednim nosowym $a$; być może jest to efekt nieodległego w czasie okresu rozwojowego, w którym obie nosówki miały zbliżoną barwę, choć 
Tabela 2. Oznaczanie palatalności $l \mathrm{w}$ drukach i listach w zależności od kontekstu fonetycznego

\section{Druki}

liczba

Pozycja fonetyczna

liczba

\begin{tabular}{rrrrr}
\hline$+e$ & 101 & 4,4 & 37 & 77,1 \\
\hline$+a$ & 87 & 2,8 & 86 & 79,6 \\
\hline$+e$ & 1538 & 2,5 & 802 & 71,0 \\
\hline$+o$ & 99 & 1,5 & 86 & 47,8 \\
\hline$+a$ & 356 & 1,5 & 350 & 62,6 \\
\hline$+u$ & 106 & 0,7 & 316 & 87,3
\end{tabular}

Źródło: opracowanie własne.

mogły występować w obu postpozycjach: palatalnej i niepalatalnej - co mogło przyczyniać się do zjawiska mieszania się obu zależności kontekstowych (w tym przypadku uogólniania związku z palatalną spółgłoską poprzedzającą nosówkę) [zob. Osiewicz 2002: 66] ${ }^{11}$. Niewykluczone też, że jest to refleks nieuchwytnych dziś zmian artykulacyjnych rezonansu nosowego, objawiających się również w tym zakresie silnymi wpływami antycypacyjnymi (tzw. wtórna nosowość) - za wiązaniem właściwości palatalizacyjnych nosówek z rezonansem nosowym, a nie $\mathrm{z}$ barwą, przemawia fakt, iż $\mathrm{w}$ listach poziom oznaczeń palatalności $l$ przy obu samogłoskach jest niemal identyczny (i - dodatkowo nieco wyższy dla pozycji przed nieprzednim $a$ ).

Oznaczanie palatalności $l \mathrm{w}$ drukach polskich z XVI wieku wykazuje też zależność od czynników morfologicznych. $Z$ analizy struktury statystycznej morfemów poświadczających to zjawisko wynika, że zdecydowana większość zapisów tego typu (1706 razy, 75\%) wystąpiła w ograniczonej liczbie morfemów (60 morfemów o frekwencji wyższej niż średnia $\mathrm{F}=8$, co stanowi $20 \%$ z 307 leksemów poświadczających zapisy z l'); dodatkowo podkreślić należy, że znaczna liczba poświadczeń form z oznaczoną palatalnością $l$ to zapisy

11 Choć pamiętać należy, że związek artykulacyjny między przednią artykulacją nosówki a palatalnością poprzedzającej je spółgłoski został do XVI wieku zatarty co najmniej dwukrotnie: w wyniku przegłosu polskiego i wskutek zrównania barwy obu prasłowiańskich samogłosek do środkowego, niepalatalnego a [Klemensiewicz i in. 1981: 103-105; Koneczna 1965: 55-56, 114-116]. 
zlokalizowane w 14 (5\%) najczęściej notujących to zjawisko morfemach (888 razy, 39\%): ale 115 razy, źle 97 razy, wszelak(-) 94 razy, -lewać 84 razy, myśl75 razy, wiel- 68 razy, krol- 61 razy, lekar- 53 razy, lud- 49 razy, dla 44 razy, -ślep- 40 razy, ślach- 37 razy, dal- 36 razy, wol- 35 razy. Struktura statystyczna morfemowego przekroju poświadczeń $l$ ' w listach prezentuje się bardzo podobnie: liczba morfemów o frekwencji wyższej niż średnia $\mathrm{F}=14$ wynosi 17 i generuje znaczącą większość odnotowanych w tej grupie tekstów zapisów $l$ ' (1334 razy, 80\%); również w przypadku listów znaczna (a nawet przeważająca) liczba zapisów l' wystąpiła w bardzo ograniczonej liczebnie grupie morfemów (6, czyli 5\% wszystkich morfemów notujących zapisy z oznaczonym palatalnym $l$; łączna liczba ich wystąpień to 963 razy, czyli 57\% wszystkich zapisów l'): krol- 342 razy, ale 216 razy, lud- 148 razy, wol- 116 razy, dla 79 razy, wiel- 62 razy. Zwraca uwagę fakt, iż każdy z tych 6 morfemów wchodzi również w skład grupy morfemów najczęściej poświadczających zapisy typu „li”, „ly” w drukach. Obserwacja ta potwierdza sformułowaną wcześniej w wyniku analizy listów tezę o w dużej mierze zleksykalizowanym charakterze oznaczania palatalności $l \mathrm{w}$ pierwszej połowie XVI wieku, jednocześnie jest też dowodem na to, że w drukach zapisy te to formy przejęte z ówczesnej praktyki rękopiśmiennej.

Interesujących danych dostarcza analiza tekstowego rozkładu oznaczeń palatalności $l$. Zjawisko to zostało poświadczone w 45 tekstach, co stanowi zaledwie $25 \%$ wszystkich ekscerpowanych druków. W grupie tekstów oznaczających $l$ ' rozkład takich zapisów jest bardzo nierównomierny $-\mathrm{z}$ danych zaprezentowanych w tabeli 3 wynika, że 95\% tych poświadczeń (2171 zapisów) zlokalizowanych jest w zaledwie 10 tekstach: Calep 1010 razy, Mącz 456 razy, RejKup 355 razy, Murm 97 razy, BiałKaz 94 razy, Leop 54 razy, RejPs 47 razy, Mymer 35 razy, FalZioł 23 razy. Analizowane teksty różnią się też pod względem konsekwencji stosowania omawianych zapisów. Największym natężeniem zapisów typu „li”, „ly” odznaczają się druki wczesne: Murm 30,6\% (wyd. 1528) i Mymer ${ }^{1}$ 15,2\% (wyd. 1528), będące też jednocześnie słownikami dwujęzycznymi, które - zapewne z uwagi na zawarte w nim formy gwarowe, często nieznane drukarzom rodzimym lub obcym - nie podlegały tak restrykcyjnej korekcie pisownianej; do grupy słowników zaliczają się też późniejsze dzieła leksykograficzne notujące wysoki odsetek oznaczeń l’: Calep 39,4\% i Mącz, w którym poświadczono, co prawda, niewielkie natężenie oznaczeń palatalności $l(7 \%)$, ale za to udokumentowane imponującą liczbą 456 poświadczeń. Zupełnie wyjątkowe na tym tle są 3 teksty niespełniające powyższych kryteriów, a poświadczające relatywnie wysoki odsetek występowania omawianych oznaczeń: RejKup 22,5\% (aż 355 zapisów; dramat, wyd. 1549), Goski 17,4\% 
Tabela 3. Oznaczanie palatalności $l \mathrm{w}$ drukach - przekrój tekstowy

\begin{tabular}{|c|c|c|c|}
\hline Tekst & l' & l' (\%) & Morf. \\
\hline Calep & 1010 & 39,4 & 247 \\
\hline Mącz & 456 & 7,1 & 95 \\
\hline RejKup & 355 & 22,5 & 83 \\
\hline Murm & 97 & 30,6 & 59 \\
\hline BiałKaz & 94 & 15,5 & 30 \\
\hline Leop & 54 & 1,0 & 19 \\
\hline RejPs & 47 & 2,8 & 9 \\
\hline Mymer1 & 35 & 15,2 & 29 \\
\hline FalZioł & 23 & 0,2 & 12 \\
\hline Goski & 12 & 17,4 & 8 \\
\hline Calag & 10 & 6,3 & 10 \\
\hline SeklKat & 10 & 1,2 & 4 \\
\hline March & 9 & 4,6 & 7 \\
\hline MurzNT & 7 & 0,8 & 6 \\
\hline SkarŻyw & 7 & 0,1 & 4 \\
\hline KwiatKsiąż & 6 & 0,9 & 6 \\
\hline KlerWes & 5 & 13,5 & 4 \\
\hline ReszPrz & 5 & 0,4 & 2 \\
\hline JanNKarGórn & 4 & 13,3 & 4 \\
\hline HistJóz & 4 & 2,2 & 4 \\
\hline SeklWyzn & 4 & 1,5 & 3 \\
\hline
\end{tabular}

\begin{tabular}{lccc}
\multicolumn{1}{c}{ Tekst } & l' & l’ $(\mathbf{\%})$ & Morf. \\
\hline KrowObr & 4 & 0,1 & 2 \\
\hline RejJóz & 3 & 0,4 & 3 \\
\hline SarnStat & 3 & 0,01 & 3 \\
\hline JanNKarKoch & 2 & 4,8 & 2 \\
\hline JanNKar & 2 & 0,8 & 2 \\
\hline TarDuch & 2 & 0,7 & 2 \\
\hline RejRozpr & 2 & 0,5 & 2 \\
\hline KuczbKat & 2 & 0,2 & 2 \\
\hline SeklPieś & 1 & 3,8 & 1 \\
\hline MurzOrt & 1 & 2,0 & 1 \\
\hline BielSen & 1 & 0,7 & 1 \\
\hline PaxLiz & 1 & 0,4 & 1 \\
\hline BielSat & 1 & 0,2 & 1 \\
\hline CzahTr & 1 & 0,2 & 1 \\
\hline GostGosp & 1 & 0,1 & 1 \\
\hline KlonWor & 1 & 0,1 & 1 \\
\hline Oczko & 1 & 0,1 & 1 \\
\hline GórnRozm & 1 & 0,1 & 1 \\
\hline GórnDworz & 1 & 0,03 & 1 \\
\hline RejPos & 1 & 0,008 & 1 \\
\hline BieKron & 1 & 0,004 & 1 \\
\hline
\end{tabular}

Źródło: opracowanie własne.

(prognostyk, wyd. 1563) i BiałKaz 15,5\% (kazanie, wyd. 1574) - zaświadczają one o istnieniu żywej pisowni, a może i wymowy palatalnego l' nie tylko w połowie XVI wieku, ale też w trzecim dwudziestopięcioleniu tego stulecia.

Rozkład tekstowy omawianych wariantów graficznych uzupełnić należy analizą ich rozkładu w tekstach poszczególnych autorów. Zapisy z oznaczoną palatalnością $l$ pojawiły się w więcej niż jednym tekście u 5 autorów: Marcina 
Bielskiego ( 3 teksty, 3 zapisy, 0,01\%), Łukasza Górnickiego (2 teksty, 2 zapisy, 0,04\%), Stanisława Murzynowskiego (2 teksty, 8 zapisów, 0,8\%), Mikołaja Reja (5 tekstów, 408 zapisów, 2,3\%) i Jana Seklucjana (3 teksty, 15 zapisów, $1,4 \%)$. Z przedstawionych danych wynika, że najwyższym poziomem oznaczeń palatalności $l$ odznaczają się teksty Reja, stosunkowo często pojawiają się one też u Seklucjana (ponadto poświadczone zostały we wszystkich ekscerpowanych tekstach tego autora). Poświadczenia zapisów „li” przed samogłoską w tekstach Seklucjana mogą być jednak uzależnione od zwyczajów drukarskich - wszystkie teksty tego autora ukazały się w oficynach królewieckich (Jana Daubmanna i Jana Weinreicha), które zgodnie odznaczają się stosunkowo wysokim odsetkiem notowań tego wariantu graficznego (zob. niżej). Nie ulega natomiast wątpliwości, że w przypadku tekstów Rejowych zapisy z oznaczoną palatalnością $l$ to refleks grafii pisarza - świadczy o tym zarówno fakt, że obecność ich nie wykazuje zależności od drukarni (Helena Unglerowa, Aleksander Aujezdecki, Maciej Wirzbięta, Maciej Szarfenberg), jak i świadectwo rękopiśmiennego pokwitowania wystawionego przez autora Zwierzyńca w 1569 roku, w którym pojawiają się 2 zapisy tego typu: lyata, podolyv 'Podolu' (obok zapisów z „l”': ZZezwolenia 'z zezwolenia', wlvblynye 'w Lublinie') [zob. Kuraszkiewicz 1986a: 613-614, 1986b: 45].

Przegląd natężenia poświadczeń zapisów $l$ palatalnego w drukach uwzględniający pochodzenie ich autorów wydaje się potwierdzać sformułowaną w toku analizy listów [Osiewicz 2002: 67-69] tezę o północnopolskim charakterze procesu depalatalizacji palatalności tej spółgłoski. $Z$ danych zawartych $w$ tabeli 4 wynika, że teksty o proweniencji wielkopolskiej i mazowieckiej przejmują z rękopiśmiennych podstaw znikomą liczbę zapisów poświadczających palatalne $l$ (Wielkopolska $-0,5 \%$, Mazowsze $-0,2 \%$ ). W tekstach pochodzących z regionów południowopolskich i z kresów południowych odsetek takich przejęć jest wyższy, często znacznie: Śląsk - 11,5\%, Małopolska - 2,7\%, Sieradzkie - 1,4\%, Ruś Czerwona - 1,0\%. Przy porównywaniu zgromadzonych danych należy zachować ostrożność w odniesieniu do wskazań charakteryzujących Śląsk: liczba tekstów reprezentująca ten region jest niewielka (2 teksty), a wysoki wskaźnik wystąpień w nich oznaczeń palatalności $l$ jest zasługą słownika z początku wieku (Mymer ${ }^{1} 35$ razy, 15\%), choć zauważyć należy, że współtworzący tę grupę Calag charakteryzuje się również stosunkowo wysokim natężeniem wystąpień zapisów typu „li”, „ly” (10 razy, 6,3\%). Podobną ostrożność przyjąc należy przy interpretacji liczb odnoszących się do tekstów autorów z Sieradzkiego, są one bowiem generowane niemal wyłącznie przez słownik Mączyńskiego (456 razy) - po ich usunięciu z zestawienia palatalność $l$ poświadczona jest $\mathrm{w}$ tym regionie tylko 3 zapisami. Nie ulega jednak wąt- 
pliwości, że w obu wspomnianych przypadkach obecność w tych regionach silnej, rękopiśmiennej tradycji oznaczania palatalności $l$ została poświadczona i można je zaliczyć do grupy regionów przejawiających tendencję konserwatywną w omawianym zakresie. Dane dotyczące Małopolski i Rusi Czerwonej nie budzą żadnych wątpliwości - ich reprezentacja jest różnorodna zarówno pod względem zasobu tekstowego (Małopolska 13 tekstów, Ruś 9 tekstów), jak i pod względem genologicznym (Małopolska: literatura specjalna - 4 teksty, proza narracyjna -2 teksty, proza polemiczno-religijna -1 tekst, literatura polityczna 1 tekst, poematy panegiryczne - 1 tekst, modlitewniki -1 tekst, dramaty -1 tekst, kazania - 1 tekst, słowniki - 1 tekst; Ruś: literatura specjalna -2 teksty, dramaty -2 teksty, thumaczenia Biblii -2 teksty, liryka -1 tekst, dialogi -1 tekst, postylle -1 tekst) czy autorskim (Małopolska - 10 autorów, Ruś -5 autorów).

Tabela 4. Oznaczanie l'w drukach - zróżnicowanie regionalne

\begin{tabular}{lccc} 
Region & $\begin{array}{c}\text { Liczba tekstów } \\
\text { oznaczających } \boldsymbol{l} \text {, }\end{array}$ & $\begin{array}{c}\text { Liczba } \\
\text { oznaczeń } \boldsymbol{l} \text {, }\end{array}$ & $\begin{array}{c}\text { Odsetek } \\
\text { oznaczeń } \boldsymbol{l} \boldsymbol{}\end{array}$ \\
\hline Mazowsze & 8 & 41 & 0,2 \\
\hline Małopolska & 11 & 218 & 2,7 \\
\hline Wielkopolska & 5 & 20 & 0,5 \\
\hline Sieradzkie & 5 & 459 & 1,4 \\
\hline Ruś Cz. & 9 & 488 & 1,0 \\
\hline Śląsk & 2 & 45 & 11,5
\end{tabular}

Źródło: opracowanie własne.

Powyższe ustalenia uzupełnia analiza oznaczeń palatalności $l \mathrm{w}$ drukach uwzględniająca miejsce ich wydania. $Z$ danych przedstawionych $w$ tabeli 5 wynika, że najwyższym odsetkiem poświadczeń oznaczeń typu „ly”, „li” odznaczają się drukarnie królewieckie (8 druków, 7,8\% zapisów l z oznaczeniem palatalności); pod tym względem wyraźnie przodują oficyny Aleksandra Aujezdeckiego (3 teksty, 14,2\% zapisów z oznaczeniem palatalności) i Jana Daubmanna (3 teksty, 6,9\% zapisów z palatalnym $l$ ). Zauważyć jednak należy, że wysoki wskaźnik oznaczeń palatalności $l \mathrm{w}$ obu drukarniach zależny jest tylko od dwóch tekstów: słownika Jana Mączyńskiego w przypadku drukarni Daubmanna (456 oznaczeń z 463) oraz Kupca autorstwa pochodzącego z Rusi Czerwonej Mikołaja Reja w przypadku drukarni Aujezdeckiego (355 ozna- 
czeń z 366). Podkreślić jednak należy, że drukarnie królewieckie odznaczają się obecnością omawianych zapisów w niemal wszystkich drukach zgromadzonych w bazie materiałowej SXVI (8 tekstów z 9, zob. też wyżej). Wysoki odsetek zapisów l' poświadczony został również w obydwu drukach pochodzących z wrocławskich oficyn Kryspina i Jana Szarfenbergów ${ }^{12}$ (2 teksty: Calag i Goski; 22 razy, 9,6\%). Wśród drukarń krakowskich poświadczających zapisy palatalnego $l \mathrm{w}$ więcej niż jednym tekście na czoło wysuwa się drukarnia Hieronima Wietora, z której pochodzą 4 teksty (z 6 obecnych w elektronicznej bazie źródłowej SXVI) poświadczające takie oznaczenia (March, Murm, HistJóz, KlerWes; 116 razy, 15,7\%); po usunięciu z tego zestawienia danych dotyczących słownika Murmeliusza wskazania dotyczące wystąpień zapisów $l$ 'w pozostałych 3 tekstach nadal są na tle pozostałych drukarń krakowskich wysokie: 18 razy, 4,3\%. Zwracają uwagę również druki Macieja Szarfenberga, wśród których większość ( 3 z 4) notuje analizowane oznaczenia - są to jednak teksty, w których wysoki poziom oznaczeń palatalności $l$ zależny jest raczej od czynników chronologicznych i gatunkowych (wczesny chronologicznie słownik Mymera) oraz idiolektalnych (teksty Reja: przekład Psatterza i Krótka rozprawa między trzema osobami). Odnotować należy, że w elektronicznej bazie źródłowej SXVI druki pochodzące z oficyn Hieronima Wietora i Macieja Szarfenberga należą (obok drukarni Unglera i Hallera) do grupy tekstów wczesnych (lata 20., 30. i 40. XVI wieku, okresy: I i II), być może zatem w ich przypadku o stosunkowo wysokim pułapie wystąpień zdecydował również wspominany już czynnik chronologiczny; bardzo niski wskaźnik notowań takich zapisów w chronologicznie należących do tej samej grupy drukach Unglerowych (tylko 3 teksty z 10; 28 zapisów, 0,3\%) skłania do przyjęcia ostrożnego wniosku o częściowym wpływie czynników drukarskich na zakres oznaczania palatalności $l$ w XVI wieku.

Podsumowując, stwierdzić należy, że w większości szczegółów z rzadka poświadczane $\mathrm{w}$ drukach oznaczenia palatalności $l$ pozostają $\mathrm{w}$ zgodzie z pisownią rękopisów, z których zostały przejęte. Najwyższy odsetek zapisów z l' charakteryzuje teksty wydrukowane w pierwszej połowie stulecia, najczęściej też poświadczone zostały one w pozycji przed samogłoskami przednimi oraz przed tylną samogłoską nosową, co dość dokładnie odzwierciedla tendencję fonetyczną zaznaczającą się w źródłach rękopiśmiennych z lat 1525-1548 (wyjątek stanowią tu oznaczenia w pozycji przed samogłoską wysoką $u$ ). Zbieżny z tekstami rękopiśmiennymi pozostaje też morfemowy zasięg wystę-

12 Była to jedna oficyna prowadzona przez ojca Kryspina i jego syna Jana, który po śmierci ojca kontynuował działalność wydawniczą [SXVI I: CXXX]. 
Tabela 5. Oznaczanie palatalności $l \mathrm{w}$ drukach - oficyny drukarskie

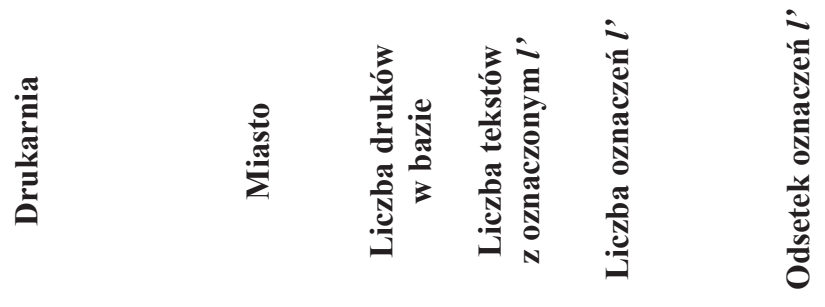

\begin{tabular}{llrrrr}
\hline Januszowski J. & Kraków & 27 & 5 & 11 & 0,07 \\
\hline Kobyliński W. & Kraków & 2 & 1 & 1 & 0,4 \\
\hline Siebeneicher J. & Kraków & 6 & 2 & 2 & 0,2 \\
\hline Siebeneicher M. & Kraków & 6 & 2 & 2 & 0,01 \\
\hline Szarfenberg Mac. & Kraków & 4 & 3 & 84 & 3,6 \\
\hline
\end{tabular}

\begin{tabular}{|c|c|c|c|c|c|c|}
\hline $\begin{array}{l}\text { Szarfenberga } \\
\text { M. Dziedzice }\end{array}$ & Kraków & 1 & 1 & 54 & 0,9 & \\
\hline $\begin{array}{l}\text { Szarfenberger } \\
\text { Mik. }\end{array}$ & Kraków & 4 & 1 & 2 & 0,2 & \\
\hline Szarfenberger S. & Kraków & 3 & 1 & 94 & 15,5 & \\
\hline Ungler F. & Kraków & 5 & 2 & 25 & 0,2 & \\
\hline Unglerowa H. & Kraków & 5 & 1 & 3 & 0,4 & \\
\hline Wietor H. & Kraków & 6 & 4 & 116 & 15,7 & \\
\hline Wirzbięta M. & Kraków & 21 & 5 & 8 & 0,03 & 0,5 \\
\hline Aujezdecki A. & Królewiec & 3 & 3 & 363 & 14,2 & \\
\hline Daubmann J. & Królewiec & 4 & 3 & 463 & 6,9 & \\
\hline Weinreich J. & Królewiec & 2 & 2 & 14 & 1,3 & 7,8 \\
\hline Wolrab J. & Poznań & 1 & 1 & 5 & 0,4 & \\
\hline $\begin{array}{l}\text { Wolraba } \\
\text { J. Dziedzice }\end{array}$ & Poznań & 1 & 1 & 1 & 0,2 & 0,3 \\
\hline Szarfenberg K., J. & Wrocław & 2 & 2 & 22 & 9,6 & 9,6 \\
\hline Druk. Radziwiłł. & Wilno & 5 & 1 & 7 & 0,07 & 0,07 \\
\hline b. dr. & Lyon & 1 & 1 & 1010 & 39,4 & 39,4 \\
\hline
\end{tabular}

Źródło: opracowanie własne. 
powania analizowanego zjawiska i fakt wysokiego stopnia zleksykalizowania oznaczania palatalności $l$. Analiza tekstowego zakresu zapisów typu „ly”, „li ujawniła grupę tekstów odznaczających się wyjątkowo wysokim odsetkiem ich wystąpień - tworzą ją teksty wczesne (z lat 20. XVI wieku) oraz słowniki, w których w mniejszym niż zwykle zakresie modernizowano pisownię podstawy rękopiśmiennej. Większą skłonność do sygnalizowania palatalności $l$ wykazują też teksty autorów pochodzących z południowych i wschodnich dzielnic Rzeczypospolitej, zwłaszcza z Małopolski oraz z Rusi Czerwonej (a wśród tych ostatnich szczególnie często w tekstach Mikołaja Reja), co pozostaje w zgodzie z ustaleniami dotyczącymi zapisów palatalnego $l \mathrm{w}$ listach polskich. Analizowane zapisy w mniejszym natomiast stopniu wykazują związek w miejscem wydania tekstów; pod tym względem odznaczają się jedynie drukarnie królewieckie oraz wrocławska oficyna Szarfenbergów, a wśród drukarń krakowskich - oficyny Hieronima Wietora i Macieja Szarfenberga.

Podkreślić należy, że związek analizowanej pisowni ze zjawiskiem procesu depalatalizacji $l$ ' w polszczyźnie XVI wieku nie jest oczywisty. Nie ulega, co prawda, wątpliwości, że u podstaw zapisów „ly” i „li” w pozycji przedsamogłoskowej leży zjawisko palatalności tej spółgłoski, jednak wydaje się, że w ówczesnych rękopisach ma ono już charakter konwencjonalny, służący tylko sygnalizowaniu opozycji fonologicznej między zębowym $\ell$ a dziąsłowym (ale już niepalatalnym) $l$. Kwestia ta wymaga dalszych analiz, uwzględniających znacznie obszerniejszy objętościowo i rozleglejszy chronologicznie materiał rękopiśmienny - ciekawych informacji w tym zakresie dostarczyć może obserwacja momentu pojawiania się w tekstach rękopiśmiennych z XVI wieku „nowego" zwyczaju sygnalizowania opozycji $t: l$ przejętego z pisowni druków i dynamiki wypierania przez nią dawnego sposobu oznaczania spółgłoski kontynuującej etymologiczne l' [zob. np. Stęplewski, Osiewicz 2004: 367].

\section{Bibliografia}

Źródła (wraz ze skrótami stosowanymi w tekście)

Listy I - Rymut Kazimierz, red. (1998), Listy polskie XVI wieku, t. 1: Listy z lat 1525-1548 ze zbiorów Władystawa Pociechy, Witolda Taszyckiego i Adama Turasiewicza, Polska Akademia Umiejętności, Kraków.

Listy II - Rymut Kazimierz, red. (2001), Listy polskie XVI wieku, t. 2: Listy z lat 1548-1550 ze zbiorów Władystawa Pociechy, Witolda Taszyckiego i Adama Turasiewicza, Polska Akademia Umiejętności, Kraków. 
SXVI - Mayenowa Maria Renata i in., red. (1966-2020), Słownik polszczyzny XVI wieku, t. 1-38, Zakład Narodowy im. Ossolińskich - Instytut Badań Literackich PAN Wydawnictwo, Wrocław-Warszawa.

Korpus źródłowy Słownika polszczyzny XVI wieku - http://spxvi.edu.pl/korpus/teksty/ [dostęp: 28 sierpnia 2019].

\section{Literatura}

Cygal-Krupowa Zofia (1979), Szesnastowieczne edycje „Dictionarii Ioannis Murmellii variarum rerum...". Czesść I. Uwagi ogólne. Ortografia, fonetyka, cechy dialektyczne, Państwowe Wydawnictwo Naukowe, Warszawa.

Dejna Karol (1993), Dialekty polskie, Zakład Narodowy im. Ossolińskich, Wrocław.

Kamińska Krystyna (1953), Pisownia druków polskich XVI wieku, „Prace Polonistyczne", t. 11, s. 5-28.

Klemensiewicz Zenon, Lehr-Spławiński Tadeusz, Urbańczyk Stanisław (1981), Gramatyka historyczna języka polskiego, Państwowe Wydawnictwo Naukowe, Warszawa.

Koneczna Halina (1965), Charakterystyka fonetyczna języka polskiego na tle innych języków słowiańskich, Państwowe Wydawnictwo Naukowe, Warszawa.

Kuraszkiewicz Władysław (1986a), Uwagi o języku Mikołaja Reja, w: tenże, Polski język literacki. Studia nad historia i struktura, Państwowe Wydawnictwa Naukowe, Poznań, s. 609-622.

Kuraszkiewicz Władysław (1986b), Zmiany redakcyjne w tekstach staropolskich, „Studia Warmińskie", t. 28, s. 37-49.

Lisowski Tomasz (2001), Grafia druków polskich z 1521 i 1522 roku. Problemy wariantywności i normalizacji, Wydawnictwo Naukowe UAM, Poznań.

Oestrreicher Henryk (1927), Nieco o dziale polskim w jedenastojęzycznym słowniku Kalepina z r. 1590, „Prace Filologiczne”, t. 12, s. 465-473.

Osiewicz Marek (2002), Rozwój XVI-wiecznego l miękkiego w języku polskim, „Slavia Occidentalis", nr 59, s. 63-70.

Osiewicz Marek (2007), Wariantywność leksemów w zakresie nieseryjnych zmian fonetycznych w listach polskich z pierwszej połowy XVI wieku, Wydawnictwo Poznańskiego Towarzystwa Przyjaciół Nauk, Poznań.

Osiewicz Marek (2013), Wariantywność graficzna „, Ksiag o gospodarstwie” Piotra Krescentyna z 1549 roku. Studium przypadku, Wydawnictwo Rys, Poznań.

Osiewicz Marek (2016), Graficzne warianty techniczne w „Ksiegach o gospodarstwie” (Kraków 1549, H. Unglerowa), „Prace Filologiczne”, t. 69, s. 317-334.

Osiewicz Marek (2017), Graficzne i fonetyczne warianty techniczne w polskiej edycji „Żywotów filozofów” Mikuláša Konáča (F. Ungler, Kraków 1535), „Poznańskie Studia Polonistyczne. Seria Językoznawcza”, t. 24 (44), nr 1, s. 117-127. 
Osiewicz Marek, Piotrowska Agnieszka K. (2007), ,,Stownik polszczyzny XVI wieku” jako podstawa materiałowa badań nad regionalnym zróżnicowaniem stownictwa, w: Leksykalno-stylistyczne zjawiska w polszczyźnie ogólnej, red. Elżbieta Skorupska-Raczyńska, Joanna Rychter, Wydawnictwo Państwowej Wyższej Szkoły Zawodowej w Gorzowie Wielkopolskim, Gorzów Wielkopolski, s. 63-73.

Stęplewski Artur, Osiewicz Marek (2004), Właściwości językowe listów Stanisława Koszuckiego z pierwszej polowy XVI wieku, „Studia Językoznawcze. Synchroniczne i diachroniczne aspekty badań polszczyzny”, t. 3, s. 363-373.

Stieber Zdzisław (1962), Rozwój fonologiczny języka polskiego, Państwowe Wydawnictwo Naukowe, Warszawa.

Stieber Zdzisław (1974), Rozwój prastowiańskich L i L'w języku polskim, w: V pamet na prof. Stojko Stojkov (1912-1969): ezikovedski izsledvaniâ, red. Lûbomir Andrejčin, B" lgarska akademiâ na naukite, Sofia, s. 73-76.

\section{Marek Osiewicz}

\section{Marking of Palatal $l$ in Polish Sixteenth-century Printed Texts}

The article presents the results of an analysis of marking of palatal $l$ in prints from the source database of Stownik polszczyzny XVI wieku (16th-century Polish language dictionary). The analysis takes into account the various conditions of this phenomenon: functional, frequency, contextual, textual, regional and publishing ones. The analysis shows that the rare records of the consonant $l$ ' certified in the papers originated from the spelling of manuscripts. Most often, they appear in printed texts from the first half of the sixteenth century, mainly in the earliest texts and dictionaries, as well as in texts originating from southern Poland and southern Borderlands. Marking of palatal $l$ in printed materials is characterised by a high degree of lexicalisation and dependence on the phonetic context and less dependent on the place of publication.

KEYwORDS: Polish 16th-century language; 16th-century prints; orthography; phonetics.

dr hab. Marek Osiewicz, prof. UAM - Zakład Nauk Pomocniczych i Edytorstwa, Instytut Filologii Polskiej, Uniwersytet im. Adama Mickiewicza w Poznaniu; zainteresowania badawcze: historia języka polskiego, polszczyzna XVI wieku, grafia, fonetyka, fonologia i morfologia historyczna, edytorstwo tekstów dawnych. 